\title{
Macro-nutrients in edible parts of food crops in the region of Moanda, Gabon
}

\author{
Jean Aubin Ondo*, Richard Menye Biyogo, Magloire Ollui-Mboulou, François Eba, \\ Joseph Omva-Zue
}

Laboratoire Pluridisciplinaire des Sciences de l'Ecole Normale Supérieure, Libreville, Gabon;

${ }^{*}$ Corresponding Author: laplus_ens@yahoo.fr

Received 11 June 2012; revised 18 July 2012; accepted 28 July 2012

\begin{abstract}
The assessment of nutritive foodstuffs quality is an important step in the estimation of dietary intake of metals. This study aimed to assess accumulation and the daily intake of macroelements magnesium, calcium, potassium and sodium in edible parts of plants grown in Moanda area. The ranges of concentrations were 246 $5645 \mathrm{mg} / \mathrm{kg}, 1167$ - 35,105 mg/kg, 158 - 12,563 $\mathrm{mg} / \mathrm{kg}$ and $88-795 \mathrm{mg} / \mathrm{kg}$ for $\mathrm{Mg}, \mathrm{Ca}, \mathrm{K}$ and $\mathrm{Na}$, respectively. $\mathrm{Mg}$ and $\mathrm{K}$ levels were significantly higher in fruits than in tubers. The trend of accumulation in the edible parts of plants was generally: $\mathrm{Ca}>\mathrm{K}>\mathrm{Mg}>\mathrm{Na}$. The daily intakes of $\mathrm{Mg}$ and $\mathrm{Ca}$ were the highest and indicated food crops in Moanda had a good nutritive quality.
\end{abstract}

Keywords: Food Crops; Macro-Nutrients; Daily Intake; Moanda

\section{INTRODUCTION}

Food crops hold an important place in well-balanced diets, and increasing consumption of vegetable and fruits is advisable [1]. For example, leafy vegetables represent an important source of proteins, vitamins and minerals for humans, and they act as buffering agents for acidic products formed during the digestion process [2]. Eleven elements are named essential nutrients. Six of them are used in large quantities (magnesium, phosphorus, potassium, calcium, nitrogen and sulphur) and are named macro-elements, and five elements are used in small quantities (boron, copper, iron, manganese and zinc) and named trace-elements. They are transferred from soil to plant and are receiving major attention [3]. The level of these elements in soils is very important for crop growth successful. If they are deficient or improperly balanced, normal growth does not occur. Plant growth maybe retarded because these elements are actually lacking in the soil, they become available too slowly. Because that, they are not adequately balanced by other nutrients. Likewise, insufficient levels of essential elements in crops can to cause serious diseases to human and animal [4-6].

WHO has recommended selective studies of individual foodstuffs as an important step in the estimation of dietary intake of metals [7]. The present work aimed to assess the accumulation of major essential nutrients $(\mathrm{Ca}, \mathrm{Mg}, \mathrm{K}$ and $\mathrm{Na}$ ) in food plants, and to estimate their daily intake by Moanda inhabitants who consume these plants.

\section{MATERIALS AND METHODS}

\subsection{Sampling, Preparation and Analyses}

Ten kinds of food crops samples were randomly collected in plantations located $15 \mathrm{~km}$ south of Moanda City, South-East Gabon $\left(13^{\circ} 10^{\prime} \mathrm{E}-13^{\circ} 15^{\prime} \mathrm{E}, 1^{\circ} 25^{\prime} \mathrm{S}-1^{\circ} 35^{\prime} \mathrm{S}\right)$ in December 2009. All collected plant samples reached the maturation. Samples were washed with distilled water and with deionized water to eliminate the air-borne pollutants and soil particles. Then they were blotted dry with tissue paper. The edible part of each vegetable was removed with a knife; they were dried at $70^{\circ} \mathrm{C}$ until constant weight. Samples were finely ground $(0.2 \mathrm{~mm})$ and kept in polyethylene bags. The selected plants are listed in Table 1.

Dried plant materials were put into a platinum dish. The capsule was introduced in an oven whose temperature was gradually increased up to $500^{\circ} \mathrm{C}$ and maintained for 2 hours. The ash obtained was mineralized by hydrochloric acid $6 \mathrm{~N}$. Calcium, magnesium, potassium and sodium in the sample were determined using atomic absorption spectrometry. Instrument optimization was set according to the manufacturer's instruction manual. Prior to analysis, the nebulizer was cleaned by aspirating $20 \mathrm{ml}$ of deionized water. The blank and standards were aspirated first, followed by the unknown samples. Deionized water was aspirated between each sample after duplicate readings were taken. The unknown element concentrations were determined from the calibration graph. 
Table 1. Studied plants and edible parts.

\begin{tabular}{ccc}
\hline Usual plant name & Edible part & Scientific name of plant \\
\hline Pepper & Fruits & Capsicum frutescens \\
Nkoumou & Leaves & Gnetum africanum \\
Okra & Fruits & Abelmoschus calei \\
Eggplant & Fruits & Solanum melongena \\
Lemon grass & Leaves & Cymbopogon citratus \\
Yam & Tubers & Dioscorea spp \\
Cassava & Leaves & Manihot esculenta Crantz \\
Amaranth & Tubers & \\
Roselle with small red leaves & Leaves & Amaranthus cruentus \\
Roselle with large green leaves & Leaves & Hibiscus sabdariffa \\
\hline
\end{tabular}

Appropriate quality assurance procedures and precautions were carried out to ensure reliability of the results. Double distilled deionized water was used throughout the study. Glassware was properly cleaned, and the reagents were of analytical grade. Standard plant reference materials (DC 73349) from China National Analysis Center for Iron were analyzed as a part of the quality assurancequality control protocol (accuracies within 100\% $\pm 10 \%$ ). Blank and drift standards were run after ten determinations to maintain instrument calibration. The coefficient of variation of replicate analyses was determined for the measurements to calculate analytical precision.

\subsection{Daily Intake of Elements}

The estimated daily intake (EDI) of elements depended on both the element concentration in crops and the amount of consumption of the respective food crop. In this study, the daily intake was considered for each edible part of plants. The estimated daily intake (EDI) of $\mathrm{Mg}, \mathrm{Ca}, \mathrm{K}$ and $\mathrm{Na}$ through edible parts of food crops was calculated according to the following Eq.1 [8]:

$$
\mathrm{DIM}=[\mathrm{M}] \times \mathrm{K} \times \mathrm{I}
$$

where $[\mathrm{M}]$ : macro-element concentration in plants $\left(\mathrm{mg} \cdot \mathrm{kg}^{-1}\right)$, $\mathrm{K}$ : conversion factor used to convert fresh part consumed of plant weight to dry weight, estimated to 0.085 , I: daily intake of consumed plants in $\mathrm{kg}$. The average daily food crops intakes for adults and children were considered to be 0.345 and $0.232 \mathrm{~kg} /$ person/day, respectively [9].

\subsection{Statistical Analysis}

Pearson's correlation coefficients were calculated and one-way ANOVA method to test the significant differences of macro-element content in edible parts of crop foods regions was employed, the level of significance was set at $p<0.05$. Statistical analyses were performed with the software XLSTAT (version 2010).

\section{RESULTS AND DISCUSSION}

\subsection{Metal Concentrations in Edible Parts of Food Crops}

Elemental composition of samples, reported on dry weight basis, is given in Table 2. On comparative basis, the tubers had less Mg and $\mathrm{K}$ levels than the fruits $(\mathrm{p}<$ 0.042 and $\mathrm{p}<0.049$, respectively). $\mathrm{Ca}$ and $\mathrm{Na}$ presented no significant differences for the three plant parts. Furthermore, certain edible parts showed interesting element uptake. Thus, Abelmoschus calei (fruits), Amaranthus cruentus and green Hibiscus sabdariffa (leaves) had the highest levels of $\mathrm{Mg}(5154,5374$ and $4247 \mathrm{mg} / \mathrm{kg}$ respectively); Solanum melongena (fruits), Amaranthus cruentus and green Hibiscus sabdariffa (leaves) had the highest levels of $\mathrm{Ca}(15,049,21,384$ and $32,721 \mathrm{mg} / \mathrm{kg}$ respectively); Capsicum frutescens had the highest levels of K (11,902 mg/kg) green Hibiscus sabdariffa (leaves) had the highest levels of $\mathrm{Na}(745 \mathrm{mg} / \mathrm{kg})$. When Gnetum africanum was the most consumed vegetable in the East region of Gabon, it was the poorest of food crops studied because it accumulated the lowest macro-element concentrations. The trend of accumulation in the edible parts of plants was generally: $\mathrm{Ca}>\mathrm{K}>\mathrm{Mg}>\mathrm{Na}$.

Macro-elements are essential minerals required for the diverse physiological and biochemical functions in the human body. They are absorbed by human and animals via foods as plants. The levels of macro-elements and others minerals in plants are influenced by their interactions and the soil nature and chemical composition [10].

Milk and other dairy products are excellent sources of calcium, both qualitatively and quantitatively. However, in some countries, milk consumption is limited due to the undesirable effects of lactose intolerance [11]. Green leafy vegetables, seeds and legumes are good alternative sources of calcium, in addition to cow milk and fish with bones. Thus, Amaranthus cruentus, green Hibiscus sabdariffa and Solanum melongena could be considered good or excellent source of calcium because its concentrations were higher than $1000 \mathrm{mg} / \mathrm{kg}$ [12].

The magnesium chief function in the body includes bone mineralization, building of proteins, and a magnesium deficiency results in osteoporosis [13]. Therefore, magnesium role with regard to bone quality and nutrition is really indispensable. In this study, fruits and leaves had higher $\mathrm{Mg}$ concentrations than tubers. $\mathrm{Mg}$, as a constituent of chlorophyll, is contained in large quantities of green leafy vegetables. Mainly centered on plant foods, the African traditional diet appears to have sufficient $\mathrm{Mg}$ 
Table 2. Metal concentrations in edible parts of dry food crops $(\mathrm{mg} / \mathrm{kg})$.

\begin{tabular}{cccccc}
\hline & & Mg & Ca & K & Na \\
\hline \multirow{4}{*}{ Leaves } & Gnetum africanum & $257 \pm 12 \mathrm{f}$ & $1382 \pm 310 \mathrm{e}$ & $168 \pm 10 \mathrm{~g}$ & $94 \pm 6 \mathrm{~d}$ \\
& Cymbopogon citratus & $562 \pm 27 \mathrm{ef}$ & $5447 \pm 380 \mathrm{~d}$ & $6652 \pm 387 \mathrm{de}$ & $479 \pm 108 \mathrm{~b}$ \\
& Amaranthus cruentus & $4248 \pm 436 \mathrm{~b}$ & $21,384 \pm 1492 \mathrm{~b}$ & $10,269 \pm 598 \mathrm{ab}$ & $471 \pm 31 \mathrm{~b}$ \\
& Hibiscus sabdariffa (red) & $2245 \pm 108 \mathrm{c}$ & $3248 \pm 549 \mathrm{de}$ & $7935 \pm 462 \mathrm{~cd}$ & $455 \pm 29 \mathrm{~b}$ \\
& Hibiscus sabdariffa (green) & $5375 \pm 258 \mathrm{a}$ & $32,722 \pm 2283 \mathrm{a}$ & $8378 \pm 1243 \mathrm{bcd}$ & $745 \pm 48 \mathrm{a}$ \\
& Manihot esculenta & $2235 \pm 107 \mathrm{c}$ & $2473 \pm 430 \mathrm{e}$ & $7974 \pm 464 \mathrm{~cd}$ & $436 \pm 28 \mathrm{~b}$ \\
Fruits & Capsicum frutescens & $2002 \pm 630 \mathrm{~cd}$ & $3032 \pm 212 \mathrm{de}$ & $11,903 \pm 1649 \mathrm{a}$ & $531 \pm 63 \mathrm{~b}$ \\
& Abelmoschus calei & $5155 \pm 247 \mathrm{a}$ & $2344 \pm 164 \mathrm{e}$ & $9932 \pm 473 \mathrm{f}$ & $457 \pm 30 \mathrm{~b}$ \\
Tubers & Solanum melongena & $1270 \pm 61 \mathrm{de}$ & $15,049 \pm 1050 \mathrm{c}$ & $4357 \pm 254 \mathrm{abc}$ & $282 \pm 16 \mathrm{c}$ \\
& Dioscorea spp & $623 \pm 30 \mathrm{ef}$ & $4010 \pm 280 \mathrm{de}$ & $3930 \pm 652 \mathrm{f}$ & $397 \pm 26 \mathrm{bc}$ \\
\hline
\end{tabular}

content. However, due the increasing consumption of fatty and animal foods, plant diet decreases.

The potassium level was $>3000 \mathrm{mg} / \mathrm{kg}$ in all samples, exception of Gnetum africanum. Na level was $<1000$ $\mathrm{mg} / \mathrm{kg}$ in all samples. $\mathrm{K}$ is an abundant ion in the plant and human cells and is required for a wide array of functions, ranging from the maintenance of electrical potential gradients across cell membranes, to the generation of turgor, to the activation of numerous enzymes [14], while $\mathrm{Na}$ is the principal ion in the fluid outside of cells. $\mathrm{Na}$ and $\mathrm{K}$ together with $\mathrm{Cl}$ are electrolytes that maintain normal fluid balance inside and outside cells and a proper balance of acid and bases in the body. A large portion of energy in the body is dedicated to maintaining sodium/potassium concentration gradients, underscoring the importance of the balance between sodium and potassium in sustaining life. Tight control of cell membrane potential is critical for heart function, as well as nerve impulse transmission and muscle contraction [15].

Nutrient correlation analysis showed significant relations between the four elements, exception between $\mathrm{Ca}$ and $\mathrm{K}$ (Table 3). Interactions between chemical elements may be both antagonistic and synergistic, and their imbalanced reactions may cause a real chemical stress in plants. These interactions may also refer to the ability of one element to inhibit or stimulate the absorption of other elements in plants. Interaction processes are controlled by several factors and these mechanisms are still poorly understood [16]. Thus, an antagonistic effect of $\mathrm{K}$ on the $\mathrm{Ca}$ content was exerted in the studied edible parts of plants. This antagonism between $\mathrm{Ca}$ and $\mathrm{K}$ is quoted in the literature [17].

\subsection{Average Daily Mineral Intake}

The levels of the minerals indicated that the local food crops could be valuable and important contributors in the
Table 3. Correlation matrix of accumulated macro-nutrients in food crops.

\begin{tabular}{ccccc}
\hline & Mg & Ca & K & Na \\
\hline Mg & 1 & & & \\
Ca & $\mathbf{0 . 5 8 5}^{* * *}$ & 1 & & \\
K & $\mathbf{0 . 6 4 5 ~}^{* * *}$ & 0.220 & 1 & \\
Na & $\mathbf{0 . 5 9 4}^{* * *}$ & $\mathbf{0 . 4 9 1}^{* *}$ & $\mathbf{0 . 6 6 7}^{* * *}$ & 1 \\
\hline
\end{tabular}

diets of people of Gabon. The mean food crops contribution of daily intakes and the recommended Intakes of $\mathrm{Mg}$, $\mathrm{Ca}, \mathrm{K}$ and $\mathrm{Na}$ for both adults and children were presented in Table $4[18,19]$. The average daily intake was 5.1 $157.6 \mathrm{mg} /$ day for $\mathrm{Mg}, 27.2-959.6 \mathrm{mg} /$ day for $\mathrm{Ca}, 3.3$ $349.0 \mathrm{mg}$ /day for $\mathrm{K}$ and $1.9-21.9 \mathrm{mg} /$ day for $\mathrm{Na}$. In general, local food crops offered greater nutritional contributions to the recommended intakes of $\mathrm{Mg}$ and $\mathrm{Ca}(2 \%$ $-82 \%$ and $3 \%-81 \%$ of recommended daily intakes, respectively) than $\mathrm{K}$ and $\mathrm{Na}(2 \%-8 \%$ and $0 \%-2 \%$ of recommended daily intakes, respectively). Furthermore, because of the high recommended daily intakes of $\mathrm{Mg}$ between children and adults, contributions to this element were more two times for children than for adults.

\section{CONCLUSION}

The mineral composition of food crops in this study showed that they could be rich sources of macro-nutrients, and contribute significantly to daily intake of calcium and magnesium, particularly. International and national health agencies are working in the world to knowledge the food composition and developing new standards, but in developing countries like Gabon these studies are still scarce or lacking. Thus, more studies could be led in the order to assess the complete nutritional contribution of principal meals. 
Table 4. Estimated daily intake of metals by edibles parts of plants of Moanda.

\begin{tabular}{|c|c|c|c|c|c|c|c|c|c|}
\hline & & \multicolumn{2}{|c|}{$\mathrm{Mg}$} & \multicolumn{2}{|c|}{$\mathrm{Ca}$} & \multicolumn{2}{|c|}{$\mathrm{K}$} & \multicolumn{2}{|c|}{$\mathrm{Na}$} \\
\hline & & Children & Adults & Children & Adults & Children & Adults & Children & Adults \\
\hline \multirow{6}{*}{ Leaves } & Gnetum africanum & 5.1 & 7.5 & 27.2 & 40.5 & 3.3 & 4.9 & 1.9 & 2.8 \\
\hline & Cymbopogon citratus & 11.1 & 16.5 & 107.4 & 159.7 & 131.2 & 195.1 & 9.4 & 14.0 \\
\hline & Hibiscus sabdariffa (red) & 44.3 & 65.8 & 64.0 & 95.2 & 156.5 & 232.7 & 9.0 & 13.3 \\
\hline & Hibiscus sabdariffa (green) & 106.0 & 157.6 & 645.3 & 959.6 & 165.2 & 245.7 & 14.7 & 21.9 \\
\hline & Amaranthus cruentus & 83.8 & 124.6 & 421.7 & 627.1 & 202.5 & 301.1 & 9.3 & 13.8 \\
\hline & Manihot esculenta & 44.1 & 65.6 & 48.8 & 72.5 & 157.2 & 233.8 & 8.6 & 12.8 \\
\hline \multirow{3}{*}{ Fruits } & Capsicum frutescens & 39.5 & 58.7 & 59.8 & 88.9 & 234.7 & 349.0 & 10.5 & 15.6 \\
\hline & Abelmoschus calei & 101.6 & 151.2 & 46.2 & 68.7 & 195.9 & 291.2 & 9.0 & 13.4 \\
\hline & Solanum melongena & 25.0 & 37.2 & 296.8 & 441.3 & 85.9 & 127.8 & 5.6 & 8.3 \\
\hline \multirow{3}{*}{ Tubers } & Dioscorea spp & 12.3 & 18.3 & 79.1 & 117.6 & 77.5 & 115.2 & 7.8 & 11.6 \\
\hline & Manihot esculenta & 8.1 & 12.1 & 60.9 & 90.6 & 106.6 & 158.6 & 9.5 & 14.1 \\
\hline & Recommended Intakes for Individual Elements ${ }^{1}$ & 130.0 & 420.0 & 800.0 & 1300.0 & 3800.0 & 4700.0 & 1200.0 & 1500.0 \\
\hline
\end{tabular}

1: $[18,19]$.

\section{ACKNOWLEDGEMENTS}

The authors acknowledge Edna Michelle BISSO BI MBA and Agnès Yolaine MIGUIBA MAROGA for their corrections and critics, and Jean Félix NDZIME for his technical assistance in laboratory analysis.

\section{REFERENCES}

[1] Kawashima, L.M. and Soares, L.M.V. (2003) Mineral profile of raw and cooked leafy vegetables edible in Southern Brazil. Journal of Food Composition and Analysis, 16, 605-611. doi:10.1016/S0889-1575(03)00057-7

[2] Akbar, J.F., Ishaq, M., Khan, S., Ihsanullah, I., Ahmad, I. and Shakirullah, M. (2010) A comparative study of human health risks via consumption of food crops grown on wastewater irrigated soil (Peshawar) and relatively clean water irrigated soil (lower Dir). Journal of Hazardous Materials, 179, 612-621. doi:10.1016/j.jhazmat.2010.03.047

[3] Adeyeye, E.I. (2005) Distribution of major elements (Na, $\mathrm{K}, \mathrm{Ca}, \mathrm{Mg}$ ) in the various anatomical parts of Fadama crops in Ekiti State, Nigeria. Bulletin of the Chemical Society of Ethiopia, 19, 175-183.

[4] Ebel, H. and Gunther, T. (1980) Magnesium metabolism: A review. Journal of Clinical Chemistry \& Clinical Biochemistry, 18, 257-270.

[5] Galdes, A. and Vallée, B.L. (1983) Categories of zinc metalloenzymes. In: Sigel, H., Ed., Marcel Delkker, New York, 1-47.

[6] Young-Eun, C., Ria-Ann, R.L., Sang-Hoon, R., Ho-Yong, S., Hong-In, S., John, H.B. and In-Sook, K. (2007) Zinc deficiency negatively affects alkaline phosphatase and the concentration of $\mathrm{Ca}, \mathrm{Mg}$ and $\mathrm{P}$ in rats. Nutrition Research and Practice, 1, 113-119.

[7] World Health Organization (1985) Global environmental monitoring system. Guidelines for the Study of Dietary Intakes of Chemical Contaminants. WHO Offset Publication, Geneva.

[8] Abdu, N., Agbenin, J.O. and Buerkert, A. (2011) Phytoavailability, human risk assessment and transfer characteristics of cadmium and zinc contamination from urban gardens in Kano, Nigeria. Journal of the Science of Food and Agriculture, 91, 2722-2730. doi:10.1002/jsfa.4583

[9] Wang, X., Sato, T., Xing, B. and Tao, S. (2005) Health risks of heavy metals to the general public in Tianjin, China via consumption of vegetables and fish. Science of the Total Environment, 350, 28-37. doi:10.1016/j.scitotenv.2004.09.044

[10] Ondo, J.A. (2011) Vulnérabilité des sols maraîchers du Gabon (région de Libreville): Acidification et mobilité des éléments métalliques. Ph.D. Thesis, Université de Provence, Marseille.

[11] Scrimshaw, N.S. and Murray, E.B. (1988) The acceptability of milk and milk products in populations with a high prevalence of lactose intolerance. American Journal of Clinical Nutrition, 48, 1083-1159.

[12] Kamchan, A., Puwastien, P., Sirichakwal, P.P. and Kongkachuichai, R. (2004) In vitro calcium bioavailability of vegetables, legumes and seeds. Journal of Food Composition and Analysis, 17, 311-320. doi:10.1016/j.jfca.2004.03.002

[13] Kim, M.H., Yeon, J.Y., Choi, M.K. and Bae, Y.J. (2011) Evaluation of magnesium intake and its relation with bone quality in healthy young Korean women. Biological Trace Element Research, 144, 109-117. 


$$
\text { doi:10.1007/s12011-011-9044-7 }
$$

[14] Britto, D.T. and Kronzucker, H.J. (2008) Cellular mechanisms of potassium transport in plants. Physiologia Plantarum, 133, 637-650.

doi:10.1111/j.1399-3054.2008.01067.x

[15] Adotey, D.K., Serfor-Armah, Y., Fianko, J.R. and Yeboah, P.O. (2009) Essential elements content in core vegetables grown and consumed in Ghana by instrumental neutron activation analysis. African Journal of Food Science, 3, 243-249.

[16] Kabata-Pendias, A. (2011) Trace elements in soils and plants. 4th Edition, Taylor \& Francis Group, Boca Raton,
London, New York.

[17] Tuma, J., Skalicky, M., Tumova, L., Blahova, P. and Rosulkova, M. (2004) Potassium, magnesium and calcium content in individual parts of Phaseolus vulgaris L. plant as related to potassium and magnesium nutrition. Plant, Soil and Environment, 50, 18-26.

[18] Institute of Medicine from United States (2007) DRI values definitions in: Food and Nutrition Board, Institute of Medicine, National Academies.

[19] WHO - World Health Organization (1996) Health criteria other supporting information. Guidelines for Drinking Water Quality, Geneva, 2, 31-388. 